\title{
SEMIOSE NEGRA DECOLONIAL EM CAROLINA MARIA DE JESUS
}

\section{DECOLONIAL BLACK SEMIOSIS IN CAROLINA MARIA DE JESUS}

Mirian Ribeiro de Oliveira'

\begin{abstract}
RESUMO: objetiva-se, neste estudo, discutir a constituiçăo do signo mulher negra pelos dizeres de Maria Carolina de Jesus (2014), tomando como referência fragmentos da narrativa autobiográfica "Favela", bem como o problema de pesquisa: de que maneira se constitui a representaçấo sígnica mulher negra na produçăo textual autobriográfica de Carolina Maria de Jesus? Parte-se da hipótese de que sua condiçāo de negra é construída pelos resquícios de um colonialismo que marginaliza os subalternizados. Ancora-se nos fundamentos teóricos da Semiótica de Peirce (2008), no que se refere a signo e representaçăo, sob o olhar de Santella (1992/2000/2003) e Araújo (2004), bem como nos princípios de decolonialidade, alicerçados por Bernardino-Costa e Grosfoguel (2016), Quintero et al (2019). Quanto à metodologia, trata-se de uma pesquisa de cunho qualitativo, em que o método se retroalimenta pela fenomenologia, tendo em vista que os sentidos do signo mulher negra, inserida em seu quotidiano intersemiótico, movem o estudo.
\end{abstract}

PALAVRAS-CHAVE: Signo; Interpretante; Mulher negra; Decolonialismo.

\begin{abstract}
This study aims to discuss the constitution of the sign black woman by Maria Carolina de Jesus's words, taking as reference fragments of the autobiographical narrative "Favela", as well as the research problem: how does the sign representation of black women constitute itself in the production textual autobiography of Carolina Maria de Jesus? It starts from the hypothesis that its condition of black is built by the remnants of a colonialism that marginalizes the subordinate. It is anchored in the theoretical foundations of Peirce's Semiotics (2008), regarding sign and representation, under the eyes of Santella (1992/2000/2003) and Araújo (2004), as well as the principles of decolonialism founded by Bernardino-Costa and Grosfoguel (2016), Quintero et al (2019). As for the methodology, this is a qualitative research, in which the method feeds back on phenomenology, considering that the meanings of the sign black woman, inserted in their intersemiotic daily life, move the study.
\end{abstract}

KEYWORDS: Sign. Interpreter. Black woman. Decolonialism.

1 Doutora em Letras pela Universidade Federal da Paraíba - UFPB, Profa . efetiva da Universidadedo Estado da Bahia - UNEB - Colegiado de Letras - CAMPUS VI/Caetité-Ba. 


\section{INTRODUÇÃO}

Considerando a tessitura contemporânea, a literatura se contrapóe como lugar de denúncia e debates das construçōes sígnicas. Sob este aspecto, corrobora-se com Delleuze (2003, p. 8) ao afirmar que “Nâo podemos interpretar os signos sem desembocar em mundos que se formou em nós, que se formaram com outras pessoas". Dessa forma, este estudo pretende discutir a constituiçăo do signo mulher negra pelos dizeres de Maria Carolina de Jesus, tomando como referência fragmentos da narrativa autobiográfica intitulada "Favela", bem como o seguinte problema de pesquisa: de que maneira se constitui a representaçâo sígnica mulher negra na produçâo textual autobriográfica de Carolina Maria de Jesus? Parte-se da hipótese de que sua condiçấo de negra é construída, ao longo da narrativa, pelos resquícios de uma colonialidade preconceituosa que coloca à margem os subalternizados.

Esta pesquisa ancora-se nos fundamentos teóricos da Semiótica de Peirce (2008), no que se refere a signo e representaçấo, sob o olhar de Santella (1992/2000/2003) e Araújo (2004), bem como nos princípios de decolonialidade, alicerçados por Bernardino-Costa e Grosfoguel (2016), Quintero et al (2019), visando à discussáo do ser, ou seja, como o outro se constitui mediante os modelos eurocêntricos preestabelecidos como regra, pelos resquícios de colonialidade impregnados na tessitura das subjetividades.

Torna-se relevante dizer, ainda, que, ao utilizar os termos subalterno/subalterna, somos movidos pela teoria, já especificada, que trata dos pós-colonialismos. Todavia, na esteira de Ballestrin (2013), visando a elucidar o emprego de conceitos, convém dizer que o termo "subalterno" fora tomado emprestado de Antonio Gramsci e entendido como classe ou grupo desagregado e episódico que tem uma tendência histórica a uma unificaçâo sempre provisória pela obliteraçâo das classes dominantes. Uma linha de pensamento que passou a ser adotada por Spivak, a partir de 1985, quando escreveu o clássico artigo "Pode o subalterno falar?", numa crítica acirrada aos pós-estruturalistas. Para a autora, năo só o subalterno náo pode falar como também o intelectual pós-colonial nâo pode fazer isso por ele (BALLESTRIN, 2013). Justifica-se a discussâo por essa via conceitual, por acreditar que a narrativa autobiográfica "Favela" foi escrita por uma interpretante subalterna. Parafraseando a mentora do enunciado, dir-se-ia "Pode Carolina Maria de Jesus falar?"

Quanto à metodologia, trata-se de uma pesquisa de cunho qualitativo, em que o método se retroalimenta pela fenomenologia, tendo em vista que săo os sentidos do signo mulher negra, inserida em seu quotidiano intersemiótico, que interessam ao estudo. Logo, fragmentos textuais foram recortados, visando à análise dos conceitos já elencados, considerando os dizeres de Maria Carolina de Jesus, no que diz respeito a narrativa de si construída pelo outro.

Vale ressaltar, parafraseando Delleuze (2003), que o mundo que se formou no sujeito Carolina Maria de Jesus, em seu entorno, nâo é o mesmo daqueles que se sobrepóem na esfera social brasileira colonial: como mulher negra, ela fala de uma instância discursiva. Logo, essa dialogicidade intersemiótica é silenciada no eixo do rito literário, tendo em vista a natureza e dimensâo de seus escritos, o que os 
torna marginal à luz do cânone da literatura: existe um silenciamento em torno da literatura denominada de marginal no Brasil e na América Latina. A adjetivaçâo per si já causa estranheza e evoca uma memória de representaçấo dicotômica identitária: aquela que é de centro versus o que está à margem. É cabível dizer que se trata de uma literatura de fronteira, em que o subalterno é destituído de sua condiçăo de fala pelo apagamento estabelecido pelo dominador. Entretanto, mesmo subjugado, esse sujeito se retroalimenta pela vontade de transformar o mundo que o rodeia. Assim era De Jesus: uma negra revolucionária de seu lugar.

No que se refere à literatura enquanto instituiçấo, assim como em outras instâncias teórico-metodológicas, existe um rito, uma ordem discursiva que privilegia uns em detrimento de outros (FOUCAULT, 1996). Na instância em foco, preestabeleceu-se uma ordem chamada de cânone literário. Sucintamente, o termo cânone deriva do grego kánon e diz respeito a uma regra, modelo ou norma representada por uma obra ou um poeta. Pode significar relação ou catálogo importante, definido por autoridade reconhecida. Dessa forma, o cânone literário nada mais é do que uma seleçăo valorizada de livros e, consequentemente, de autores. Assim, como se trata de uma seleçâo, nem todos estâo autorizados a entrar nesta ordem. Em nome da qualidade estética, entre outros aspectos, provocou-se uma norma, regra, que subjugava o que devia ou nâo ser lido. Pelas vias intelectuais, a leitura tornou-se também um dispositivo hegemônico da ordem do colonizador.

Diante das assertivas supracitadas, é cabível dizer que, como negra e mulher, os dizeres de Carolina ressoaram muito pouco nos espaços literários. Todavia, tornou-se um ícone em seu meio ao publicar "Quarto de Despejo". Conforme Fernandes (2014), De Jesus escreveu de forma fragmentada, híbrida e a partir de diversos gêneros, em papéis reaproveitáveis, catados no lixo. Possuidora de um domínio literário envolvente, ganhou visibilidade nacional e internacional quando o jornalista Audálio Dantas publicou "Quarto de Despejo", vendendo mais de doze mil cópias. O citado jornalista a descobriu quando foi à favela fazer uma reportagem sobre uma favela que se expandia na beira do rio Tietê, no bairro do Canindé. Conta o autor que, em meio ao rebuliço favelado, encontrou Carolina, a negra que tinha algo a dizer. (FERNANES, 2014). Da Favela, passou a frequentar a alta sociedade paulistana. Em seus escritos, mescla gêneros e subgêneros, empreendendo com um cuidado estético autodidata, mas influenciada por consulta a dicionários, leitura de revistas, jornais e dos livros recolhidos no lixo como "Os miseráveis", de Victor Hugo, bem como poesias de Edgar Allan Poe e Caryl Chessman. "Carolina de Jesus fazia leitura, reflexâo e crítica, em prosa e poesia, de tudo o que estava ao seu alcance, como a escuta de radionovelas, das músicas, das vozes dos vizinhos, dos discursos políticos e religiosos" (FERNANDES, 2014, p. 15).

Paralelo à narrativa autobiográfica "Favela", escreve "Onde estaes Felicidade", estabelecendo uma fusăo metafórica com o nome da personagem que desaparece do lugar em que reside, ao longo da narrativa, com o estado de ser feliz ou possuir a felicidade. Em "Favela", Carolina passa a se desnudar para o leitor, apresentando as peculiaridades do lugar de onde fala, do eu que nâo se cala diante das injustiças da vida de mulher negra e favelada. Trata-se de um texto entremeado de citaçôes, construído por dois episódios: a ocupaçâo da favela e a maternidade. Neste ínterim, 
Carolina subjetiva-se pelas relaçōes estabelecidas mediante os eventos do trabalho autônomo de catadora de papel e por sua publicaçăo no jornal "O Defensor".

\section{SEMIOTIZANDO LINGUAGENS}

Afirmando que a Semiótica é a ciência que tem por objeto de investigaçăo todas as linguagens possíveis, Santaella (2003) ratifica os dizeres de Peirce (2008) ao enunciar que as linguagens estáo no mundo e nós estamos na linguagem. Dessa forma, a ciência denominada de Semiótica tem por objetivo o exame dos modos de constituiçấo de todo e qualquer fenômeno de linguagem, como fenômeno de produçâao de significaçăo e de sentido. Sua significaçâo remonta a Grécia antiga. Fernandes (2011) lembra que a palavra SEMIÓTICA vem da raiz grega "seme", como em semeiotikos, intérprete de signos. Para Peirce, segundo Araújo (2004), a lógica é a ciência dos signos e a sustentaçăo fundamental da Semiótica, doutrina geral dos signos.

Compete dizer que os estudos que tratam do signo remontam a Grécia antiga, quando a medicina já empregava a semiologia para pesquisas de imagens. Nöth (1995, p. 19) destaca que “O médico grego Galeno de Pérgamo (139-199) referiu-se à diagnóstica como sendo 'a parte semiótica' (semeiotikón méros) da medicina.". Segundo Fernandes (2011), os gregos sustentavam que o signo era um sinal, por meio do qual se representa alguma coisa: uma coisa que se duplica, uma realidade que se reproduz através de outra forma, ou, em outras palavras: o original e a cópia. Uma espécie de semiose, tratada posteriormente por Peirce (2008), para além da ideia de representaçâo, enquanto espelho de uma realidade. O enunciado signo, deriva do latim signum, que vem do grego secnom, significando cortar, extrair uma parte de, gerando em nossa língua, por exemplo, os termos secçấo, seccionar, sectário, seita, entre outros. De Platăo a Aristóteles, passando pelos estóicos e por Santo Agostinho, o signo ganhou sentido e significados diferenciadores (FERNANDES, 2011).

Todavia, sucintamente, foi no Estruturalismo de Saussure que o signo ganhou notoriedade linguística, como entidade psíquica e eminentemente social, possuidor de um caráter linear e arbitrário, numa perspectiva de um sistema abstrato e interno de língua. O signo, para o Saussure do CLG (Curso de Linguística Geral), é dicotômico e possuidor de duas faces: conceito e imagem acústica, significado e significante respectivamente. Uma visăo dual, portanto. Somado a estas afirmaçōes, é importante dizer que a eminência social do signo saussureano também o eleva ao caráter coercitivo, uma influência positivista sofrida por Saussure. Na contemporaneidade, tornou-se visível o quanto o signo se estendeu para além da visăo estruturalista.

Ademais, com um olhar aguçado para o devir científico, que se desenhava no Século XX, Saussure (2004), também no CLG, fez uma rápida e importante alusâo a outra ciência a Semiologia. Por outro lado, enquanto Saussure partia do princípio da dicotomia, pensando o signo como arbitrário, composto de duas faces distintas, Peirce (2008) o via como assimétrico: aquilo que, sob certo aspecto ou modo, repre- 
senta algo para alguém. Para Peirce (2008), o signo estabelece uma relaçăo triádica. Outro ponto elementar, diferenciador entre as teorias, é o aspecto da referência: Saussure, sob o olhar do CLG, năo considera o referente, ou seja, o exterior à língua; Peirce, citado por Santaella e Nöth (2008), ao contrário, enfatiza que a Semiótica é a ciência das linguagens semiotizadas, ou seja, dá ao signo um caráter eminentemente cultural. Para Araújo (2004, p. 56), muitos caracteres os especificam, distinguindo-os, inclusive, no tangente à arquitetura teórica. O próprio Peirce (2008) enfatiza que náo queria construir uma teoria com terminologias e/ou categorias já ditas, ou antes, concebidas, pois seu anseio era algo novo, nunca empreendido por outrem. Debruçou-se precocemente na lógica matematizada e filosófica para, após longos anos de estudos, conceber o que viria a ser a Semiótica: a linguagem de todas as linguagens - uma faneroscopia ou estudos dos fenômenos, termo oriundo do grego phaneros (o visível, o aparente, o manifesto, o fenômeno) e skopéo (olhar, observar, refletir: a faneroscopia é a descriçăo do faneron). Infere-se, destarte, que esta arquitetura filosófica, como aponta Santaella (2003), é constituída, em especial, à luz da Fenomenologia. Na faneroscopia, năo interessa descobrir novos fenômenos, mas apenas descrever as características mais gerais das aparências,

Como ciência triádica, seus elementos constituintes também o sâo e se desdobram em outras vertentes teórico-metodológicas: Fenomenologia, Ciências Normativas e Metafísica - a tríade ascendente do nascimento da teoria geral dos signos ou Semiótica e de sua categoria basilar: o signo ou semeion de origem grega, bem como de conceitos caros a Peirce - primeiridade, secundidade e terceiridade. As ciências normativas sâo três, as quais sejam, segundo a ordem das categorias ceno-pitagóricas: a estética, a ética e a lógica. Juntas, elas constituem a segunda subclasse da filosofia, quer dizer, estudam os fenômenos em sua secundidade. Isto é, năo em seu parecer ser, mas em seu caráter existencial de reatividade relativamente a nós. Consequentemente, as ciências normativas voltam-se à açấo: agimos sobre os fenômenos, reagimos a eles e vice-versa.

Assim, "a estética considera aquelas coisas cujos fins săo incorporar qualidades de sentimento, a ética, aquelas cujos fins estâo na açâo, e a lógica, aquelas cujo fim é representar algo" (PEIRCE, 2008, p. 201). Peirce, apaixonado pelas novas categorias, afirma a inter-relaçăo entre a filosofia e suas descobertas, chamadas por ele de "minhas três categorias" e/ou "os três tipos de bem" (PEIRCE, 2008, p. 199), relacionando-as ao sentimento, reaçâo e pensamento respectivamente. Quando um interpretante se depara com uma realidade sígnica, no primeiro estágio, o do sentimento/primeiridade está apenas no âmbito da observaçăo, ainda năo foi afetado pelo signo; ao abstrair dos fenômenos os sentidos, ou seja, reagindo diante deles, na secundidade, a mente do interpretante, que pode ser outro representâmen, entrará no nível da abstraçấo, passando a argumentar e contra argumentar com os constituintes representativos.

Lembrando que náo se trata pura e simplesmente de uma realidade representada ou tampouco de um ato mecânico: apesar de os estágios serem sequenciais, uma mente interpretante pode chegar imediatamente ao terceiro momento sem, contudo, pular um dos estágios. Araújo (2004) explica que năo cabe dizer, na ótica peirceana, que o pensamento espelha a realidade em que o representa mediante a linguagem 
numa relaçăo pura e simples entre enunciado e fato, visto que o próprio pensamento é um signo: "[...] Levando-se em conta que, para Peirce, o pensamento interpreta o outro que lhe serve de signo, pode se supor que náo é a chamada "realidade" em si que é representada." (ARAÚJO, 2004, p. 54-55). (GRIFOS DA AUTORA). Esclarece, ainda, que a mente do sujeito nâo é uma mente no sentido cartesiano, cujo conteúdo vem da ideia que representa as coisas: o objeto também é objeto para um signo-pensamento, na medida em que o interpreta.

Sendo assim, por uma leitura peirceana, é cabível dizer que o sujeito Carolina Maria de Jesus tornou-se uma interlocutora situada ou uma semiose em ato, vez que o sujeito náo é o centro da atividade linguística, pois é no signo, na tessitura linguística, que há intersubjetividade. "Se o signo leva à interpretaçâo, que é por sua vez outro signo, náo há uma mente funcionando como um receptáculo contendo pensamentos que representam coisas ou estado de coisas." (ARAÚJO, 2004, p. 55). Assim, De Jesus (2014) emprega uma linguagem que leva o leitor à favela, náo só pela possibilidade de representaçáo desenhada por ela mesma, mas por se constituir enquanto signo de denúncia do espaço favela, năo aceitando a condiçâo que lhe é imposta e a torna subalterna. Dessa forma, um signo remete-nos a outro signo que o representa. Como se constituiu o signo favela? E De Jesus (2014) quem nos diz:

Era o fim de 1948, surgio o dono do terreno da Rua Antonio de Barros onde estava localizada a favela. Os donos exigiram e apelaram queriam o terreno vago no praso de 60 dias. Os favelos agitavam-se. Nâo tinham dinheiro. Os que podiam sair ou comprar terreno saiam. Mas era a minoria que estava em condiçóes de sair. A maioria năo tinha recursos. Estavam todos apreensivos. Os policiais percorria a favela insistindo com os favelados para sair. Só se ouvia dizer o que será de nós? Săo Paulo modernizava-se. Estava destruindo as casas antigas para construir aranha céus. [...] vamos falar com Dr. Adhemar de Barros. [...] dentro de 3 dias eu arranjo lugar para voçeis. [...] e resolveram instalar os favelados as margens do Rio Tietê, no bairro Canindé.

A ordem era uma nova reconfiguraçăo territorial de favela, nas proximidades de um rio. Percebe-se a presença de diferentes signos nessa construçâo de lugar: donos dos terrenos, exigindo a desocupaçăo, favelados, falta de dinheiro, polícia, pessoas influentes, Rio Tietê, bairro Canindé entre outros. Uma conjuntura que passa a desenhar uma realidade nova, impregnada pelas velhas condiçôes. A linguagem enunciada pela mente interpretante faz surgir a representaçăo dos subalternos: uma identidade forjada em meio à submissâo daqueles que decidem nâo só por si, mas pelo outro, silenciado pelas circunstâncias preestabelecidas pelo poder: "os donos exigiram e apelaram queriam o terreno vago no praso de 60 dias. Os favelados agitavam-se" (DE JESUS, 2014, p. 39).

\section{OS PRINCÍPIOS DA DECOLONIALIDADE EM CAROLINA MARIA DE JESUS: UMA INTERPRETANTE DE SI MESMA}

Em se tratando de representaçâo, torna-se relevante dizer que, em "Favela", Carolina Maria de Jesus se projeta enquanto signo interpretante do lugar de onde 
fala e em que vive, visto que é sob o olhar de De Jesus (2014) que conhecemos as nuances da Favela: ela é interpretante de si e do outro, gerando outros tantos interpretantes na relaçâo que passa a estabelecer com seus leitores. O que Peirce (2008) denomina de semiose infinita. Esta representaçâo passa pelo crivo da identidade que se constrói na tessitura do texto literário. Araújo (2004, p. 52) ressalta que "todo pensamento é um signo, dirige-se ao outro." Além disso, por vezes, a narradora personagem faz uso da primeira pessoa para chamar a atençâo nâo de seu eu lírico, mas pelo fato de estar cônscia de quem é, de como se distingue dos demais e do que pensa. Os enunciados "Eu sempre tive linha" (DE JESUS, 2014, p. 61) denotam a percepçấo sígnica de Carolina.

Nessa movência de sentidos, os debates acirrados acerca da identidade e/ou da construçăo da estética de si e do outro em sua vasta literatura, enfatizam que, apesar da descentralidade ser uma característica identitária do sujeito pós-moderno, de a sociedade ser considerada uma comunidade guarda-roupa, por sua característica efêmera líquido-moderna (BAUMAN, 1998/2005), existem resquícios, ranços, deixados pelas marcas coloniais modernas que continuam impregnadas nas representaçóes que o sujeito faz de si e do outro. Inclusive, numa tentativa de normalizar esse outro pelos moldes culturais tradicionais, a saber, eurocêntricos. Os povos subjugados, entendidos como subalternos, como o negro, a mulher negra, entre outros, passam a ser elementos cruciais das discussóes à luz de conceitos como raça, identidade, resistência etc. Sob este aspecto, corroboram-se as assertivas de Bernardino-Costa e Grosfoguel (2016, p. 7):

Nesse sentido, o eurocentrismo funciona como um locus epistêmico de onde se constrói um modelo de conhecimento que, por um lado, universaliza a experiência local europeia como modelo normativo a seguir e, por outro, designa seus dispositivos de conhecimento como os únicos válidos.

Oliveira (2011), seguindo as pesquisas que tratam dos polos dicotômicos Modernidade/Pós-Modernidade, aponta o estreitamento que existe nas relaçóes do constructo do conhecimento científico, pelas vias da racionalidade exacerbada e moderna, e identidade, enfatizando o quanto o zelo europeu pela racionalidade técnica foi determinante para legitimar a normalidade, instituída como padrâo, ao ponto de anular, alijar ou mesmo extinguir o outro, quando esse outro se destoar do projeto europeu. Nesta pesquisa, ratificam-se as afirmaçōes supracitadas com os enunciados de Quintero et all (2010), ao discutir as perspectivas do decolonialismo:

A colonialidade do ser, proposta por Nelson Maldonado-Torres, entende a modernidade como uma conquista permanente na qual o constructo "raça" vem justificar a prolongaçâo da năo ética da guerra, que permite o avassalamento total da humanidade do outro. $\mathrm{O}$ autor aponta a relaçấo entre a colonialidade do saber e do ser, sustentando que é a partir da centralidade do conhecimento na modernidade que se pode produzir uma desqualificaçaáo epistêmica do outro. Tal desqualificaçăo representa uma tentativa de negaçăo ontológica. A colonialidade do ser como categoria analítica viria revelar o ego conquiro que antecede e sobrevive ao ego cogito cartesiano, pois, por trás do enunciado "penso, logo existo", oculta-se a validaçăo de um único pensamento (os outros năo pensam adequadamente ou simplesmente năo pensam) que outorga a qualidade de ser (se os outros nâo pensam adequadamente, eles năo existem ou sua existência é dispensável). Dessa forma, năo pensar em 
termos modernos se traduzirá no năo ser, em uma justificativa para a dominaçăo e a exploraçăo (QUINTERO et all, 2010, p. 7)

Observa-se que a colonialidade do ser passa pelo crivo da identidade do outro, pela falta de reconhecimento até mesmo da capacidade de pensar: refuta-se o colonizado como inoperante também no pensar. Logo, o sentido de colonizar é polissêmico e ressignifica o apagamento do outro que năo se vê nos signos (e enquanto signo) da sociedade em que vive. Sob este ângulo, é cabível dizer que, para as mentes interpretantes contemporâneas, colonizar tornou-se um conceito sígnico dinâmico, por expressar uma situaçăo cultural de relaçăo de forças antagônicas e desiguais: a sociedade colonial e a sociedade colonizada. A primeira compreende os estrangeiros de origem metropolitana, os europeus ou de raça branca nâo-metropolitanos; já a segunda, constituída pelos năo-europeus, geralmente de origem asiática, os coloured ou homens de cor. Os grupos náo desempenhavam o mesmo papel na colônia, cada um deles mantinha domínio sobre os autóctones, competindo aos de origem metropolitana a eminência do domínio política, econômica e espiritualmente. Aos demais restavam atividades comerciais intermediárias. A sociedade colonial temia a ruptura da ordem e do equilíbrio estabelecidos em seu favor. Para que isto náo ocorresse, "encastelava-se, intocável, explorando e pilhando a maioria negra, utilizando-se de mecanismos repressivos diretos (força bruta) e indiretos (preconceitos raciais e outros estereótipos)" (MUNANGA, 1988, p.11).

Parafraseando Bernardino-Costa e Grosfoguel (2016), se năo cabe um pensamento centralizador, fundamentado no cogito ergo sum, tampouco cabe dizer que o decolonialismo, enquanto campo teórico-metodológico, pertence a um único grupo de pesquisadores. Isto representaria a também colonizaçăo do conhecimento. Compete dizer, todavia, que existe, sim, um lugar, um nascedouro, que demarca suas origens: a rede de investigaçâo do pós-colonialismo, na virada do milênio, tem seu alicerce nos intelectuais da América Latina "em torno da decolonialidade ou, como nomeia Arturo Escobar (2003), em torno de um programa de investigaçâo modernidade/colonialidade" (BERNARDINO-COSTA; GROSFOGUEL, 2016, p. 16). Assim, o decolonial como rede de pesquisadores que busca sistematizar conceitos e categorias interpretativas tem uma existência bastante recente.

Pontua-se, entretanto, que, ao ser denominado de estudos pós-coloniais, nâo se admite dizer que năo mais existe o colonialismo ou que se esgotaram o domínio do poder e das relaçôes do poder-saber: ao contrário, seus efeitos perduram em colonialismos contemporâneos, como a existência de uma única variante linguística, enquanto norma/regra e/ou único capital linguístico-literário. As demais variantes sâo, quiçá, relegadas a um segundo plano. No que tange à literatura, ainda perduram tratamentos extremamente abstratos ao signo. Comprovam-se as assertivas no tratamento dispensado à linguagem literária de Maria Carolina de Jesus, refutada por aqueles que diziam "isto náo é literatura" (FERNANDES, 2014). Torna-se elementar dizer, também, que uma das maiores heranças do colonialismo sâo os racismos, em especial o racismo de cor que tem se sustentado numa sociedade denominada de pós-moderna. $O$ pós-colonialismo tem sido construído sob os auspícios da modernidade, introspectada por onde passaram os europeus como colonizadores. 
É salutar dizer que, apesar de seu nascedouro ter sido construído pelas vias da América Latina, a língua utilizada pelos pesquisadores do decolonialismo ainda é a língua inglesa. Justifica-se o uso devido ao fato de os precursores, grandes nomes da área - a saber, Walter Mignolo e Aníbal Quijano - terem seus estudos firmados na Inglaterra. Segundo Bernardino-Costa e Grosfoguel (2016), os intelectuais do terceiro mundo estavam radicados nos departamentos dos estudos culturais, nas universidades inglesas e, posteriormente, norte-americanas. Miglievich-Ribeiro (2014) explana que

[...] Walter Mignolo e Aníbal Quijano assumem o desafio epistemológico do giro decolonial que exige a vivência e o testemunho dos desmandos da colonialidade e da experiência nodal da subalternidade para tornar mais radical a crítica realizada à modernidade eurocêntrica-setentrional. No diálogo com o Grupo de Estudos Subalternos do Sul da Ásia, alguns intelectuais latino-americanos encontram pontos de contato que lhes permitiram fundar, por sua vez, no continente o Grupo Latino-Americano de Estudos Subalternos, que năo demorariam muito para que, ainda que em sintonia com os investigadores indianos, se propusessem a marcar sua diferença e originalidade. Assim é que, segundo Ballestrin (2013), a reimpressâo do clássico Colonialidad y modernidad-racionalidad, de Quijano, originalmente publicado em 1993, na revista Boundary, dá um redirecionamento da crítica pós-colonial na América Latina.

Bernardino-Costa e Grosfoguel, (2016) indicam que o pós-colonialismo como termo originou-se nas discussôes sobre a decolonizaçâo de colônias africanas e asiáticas depois da Segunda Guerra Mundial. Nesta linha de pensamento afirmam que as vozes obliteradas ou silenciadas dos subalternos também ressoaram nos estudos do historiador Ranajit Guha, derivando o Grupo de Estudos da Subalternidade do Sul da Ásia, liderado, na década de 1980, por este pesquisador. A intençáo primordial dos estudos de Guha era desmantelar a razáo colonial e nacionalista na Índia, "restituindo aos sujeitos subalternos sua condiçăo de sujeitos plurais e descentrados. [...] propunha-se a apreender a consciência subalterna silenciada no e pelo discurso colonial e nacionalista." (BERNARDINO-COSTA E GROSFOGUEL, 2016, p. 16).

Por seu turno, Ballestrin (2013, p 90), numa tentativa de síntese, ao mapear a genealogia do termo pós-colonialismo, diz que

Depreendem-se do termo "pós-colonialismo" basicamente dois entendimentos. 0 primeiro diz respeito ao tempo histórico posterior aos processos de descolonizaçáo do chamado "terceiro mundo", a partir da metade do século XX. Temporalmente, tal ideia refere-se, portanto, à independência, libertaçăo e emancipaçăo das sociedades exploradas pelo imperialismo e neocolonialismo - especialmente nos continentes asiático e africano. A outra utilizaçâo do termo se refere a um conjunto de contribuiçōes teóricas oriundas principalmente dos estudos literários e culturais, que a partir dos anos 1980 ganharam evidência em algumas universidades dos Estados Unidos e da Inglaterra.

Na síntese, o termo decolonialismo passa por um terreno de disputa, forjado no âmbito de tensôes e conflitos antagônicos. Inclusive no que diz respeito às concepçôes que o norteiam. O fato é que os estudos investigativos acerca dos menos favorecidos ou enclausurados năo só pela visăo de modernidade, contudo pelas açóes 
dela provenientes, foram suscitados desde que os europeus fincaram năo só os pés em 1492, mas uma rede de pensamento em terras que năo eram suas, trazendo em suas bagagens a intençăo de marginalizar o outro mediante uma arquitetura racionalizada denominada de modernidade. $O$ enclausuramento gerou a resistência. Afinal, a revoluçăo năo é feita apenas de proletários e burgueses. As Ciências Humanas e Sociais, as Letras e Artes fazem outro tipo de revoluçăo. Dessa forma, os princípios do decolonialismo já estavam acesos nas discussóes travadas pela tradiçăo do pensamento negro. A saber, W. E. B. Du Bois, Oliver Cox, Frantz Fanon, Cedric Robinson, Aimé Césaire, Eric Williams, Angela Davis, Zora Neale Huston, Bell Hooks etc. Todavia, a articulaçăo das ideias, "já identificada com o conceito de colonialidade - foi formulada de maneira explícita por Immanuel Wallerstein (1992). Na sequência, o conceito de Wallerstein foi retomado por Anibal Quijano, que passou a nomeá-lo como colonialidade do poder" (BERNARDINO-COSTA E GROSFOGUEL, 2016, p. 17). Acompanhando este raciocínio, Ballestrin (2013, p. 92) faz a seguinte ressalva:

Porém, existe um entendimento compartilhado sobre a importância, atualidade
e precipitaçăo da chamada "tríade francesa", Césaire, Memmi e Fanon, talvez pelo
fato de o argumento pós-colonial ter sido, pela primeira vez, desenvolvido de forma
mais ou menos simultânea. Franz Fanon (1925-1961) - psicanalista, negro, nascido
na Martinica e revolucionário do processo de libertaçâo nacional da Argélia -, Aimé
Césaire (1913-2008) - poeta, negro, também nascido na Martinica - e Albert Memmi
(1920) - escritor e professor, nascido na Tunísia, de origem judaica - foram os por-
ta-vozes que intercederam pelo colonizado quando este náo tinha voz, para usar os
termos de Spivak. (BALLESTRIN, 2013, p. 92).

Na busca do diálogo entre as vertentes teóricas do decolonialismo, semiótica e literatura, iniciamos esta subseçâo afirmando que Carolina Maria de Jesus se constrói como interpretante de si e do outro, pois em seu fazer literário evidencia a leitura de interlocuçáo de pessoas próximas a ela ou que conviviam no mesmo espaço comunitário. É perceptível que o olhar do outro para a mulher (pobre e negra) carrega estigmas enraizados na percepçâo coisificada, historicamente, pela colonizaçâo:

Sempre fui muito tolerante pensava melhores dias há de vir se Deus quiser comecei preparar o exonval do meu Joăo José. Fazia o tratamento pre Natal no Hóspital das clinicas. Eu sentia tonteiras e caia mêia inconsiente. Alguns passava-me e năo me olhava. Outros fitava-me e dizia.

Negra nova podia e pode trabalhar mas prefere embriagar-se.

Mal sabiam eles que eu năo me sentia bem alimentaçăo deficiente. (DE JESUS, 2014, p. 42-43).

A fome vivenciada por Carolina retrata as condiçôes precárias vividas por muitos brasileiros à margem da sociedade, traduzindo-se como embriaguez para aqueles acostumados a enxergar o negro como bêbado e de incapacidade laboral. Ao chamá-la de negra, a mente interpretante a coloca numa posiçấo hierárquica de subalterna, trazendo à tona uma condiçăo de inferioridade. Inocêncio (2006, p. 185) enfatiza que "na cultura visual brasileira, o corpo negro aparece como a antítese do 
que se imagina como normal". Assim se configura a representaçâo de Carolina pelo olhar do outro: estava caída náo pela fome, mas por se constituir negra e bêbada.

As vezes eu ia na Igreja Imaculada pedir păo. Quantas vezes a criança debatia no meu ventre. Quando eu chegava no meu misero barraco dêitava. Os visinhos murmurava. Ela é sosinha. Deve ser alguma vagabunda. É crença generalizada que as pretas do Brasil săo vagabundas. (DE JESUS, 2014, p.43)

Uma interpretante consciente de sua situaçăo: A história é narrada por quem a vivencia. É a própria excluída contando sua história de exclusăo. "A D. Carolina está no jornal. O que ela fez? Róubou? -Nâo é poetisa. Está dizendo que um dia há de ser escritora." (DE JESUS, 2014, p. 51). Sob o ponto de vista peirceano, é possível dizer que estamos diante de interpretantes que se dinamizam e săo forjados no bojo do quotidiano. Peirce diferencia os interpretantes em imediato e dinâmico. Vale dizer que esta dinamicidade passa pelo crivo do referente, năo no sentido do espelho da realidade, como já dito, todavia como dispositivo cultural. Santaella (1992, p. 191) demarca que o interpretante dinâmico é "o efeito efetivamente produzido pelo signo numa mente interpretadora." Em uma de suas conversas na UFBA (Universidade Federal da Bahia), no ano de 2017, Davis é categórica em dizer: "Quando a mulher negra se movimenta, toda a estrutura da sociedade se movimenta com ela, porque tudo é desestabilizado a partir da base da pirâmide social onde se encontram as mulheres negras, muda-se a base do capitalismo" (DAVIS, 2017). Maria Carolina de Jesus, um interpretante dinâmico, faz parte dessa movência de sentidos, por ser um signo cultural nâo aleatório a realidade da favela, do locus de enunciaçăo. Cabe também citar um dos grandes expoentes baiano, Milton Santos (2005), quando utiliza a máxima do direito romano, ao discutir o lugar enquanto território de pessoas: ubis pedis ibi patria (onde estāo os pés aí está a pátria). A pátria sígnica de Maria Carolina de Jesus situava-se onde os seus pés estavam fincados: com o seu texto literário, desestabilizava as estruturas estigmatizadas acerca do negro, da mulher negra, ao apresentar para a comunidade seus escritos. "A D. Carolina está no jornal. O que ela fez? Róubou? -Nâo é poetisa. (DE JESUS, 2014, p. 51). Os enunciados "é poetisa" desestruturam os preconceitos pegajosos historicamente construídos acerca do negro ao mesmo tempo em que, junto ao questionamento "Roubou?", provocam os antagonismos marginais vivenciados na condiçâo de mulher negra.

Guimarâes (2014) fala de Carolina como uma mulher comprometida em ser mulher e negra, ao romper com a predeterminaçăo social relegada para o negro na pirâmide brasileira. Ela năo precisou estar no lugar da mulher branca para dar voz ao seu corpo, ao fato de ser măe. Ultrapassando as normas, Carolina era uma vanguardista, pois o năo silenciamento de sua voz já anunciava o rompimento de paradigmas no âmbito da Literatura.

De Jesus (2014) tinha consciência de sua situaçăo precária, mas era mâe. Assim, levantava-se em meio às adversidades do dia a dia de uma mulher solitária: pobre, negra e máe solteira, atributos que a desqualificavam junto à sociedade patriarcal e dogmática. Uma subalterna consciente dos enfrentamentos que tinha pela frente: enxugava as lágrimas e recomeçava. Em suas escrituras, a leitura que faz de si mesma leva o leitor a construir uma imagem sígnica representativa de 
uma Carolina forte, pronta para a luta. Há um empoderamento nas palavras de De Jesus. Ouvi-la, é oportuno para o momento:

“[...] voltei pra casa fiz um mingau de fubá. Puis gurdura adôcei e deu uma colherada para a menina [...] Eu nunca vi alguém ter filho num dia e levantar no outro. [...] Eu quase náo podia andar de fraqueza. Foi a fome que impeliu-me a levantar. [...] Seis dias depois fui catar papel. Cancei. Sentei. Tive vontade de chorar. Pensei: As lágrimas năo soluciona as dificuldades (DE JESUS, 2014, p. 70-71):

Acrescenta-se, ainda, que, ao assumir essa postura, De Jesus (2014) passa a atrair o leitor náo para uma perspectiva literária de estilo padronizado, mas para o locus do acontecimento, provocando no leitor, também interpretante, um deslocamento do olhar crítico literário para os espaços periféricos que se tornam reais, simbólicos e, portanto, representativos, produtores de uma intersemiose com o mundo que o circunda. O que leva Guimarâes (2014) a dizer:

Como escritora, fato concreto e inquestionável, Carolina superou em muito o dito canônico que náo a reconheceu como tal e ainda hoje reluta em fazê-lo. Ao estrear publicamente com o livro Quarto de Despejo, em 1960, resultado de seu diário manuscrito (temido por sua vizinhança) mexeu com as bases da construçăo da Literatura Nacional, por isso sua obra foi um sucesso, mas năo foi absorvida, talvez a palavra que se encaixe melhor seja digerida (GUIMARÂES, 2014, p. 79).

Assim, pela emergência de seu dizer, De Jesus (2014) faz circular uma produçâo que se estabelece como literatura de fronteira, empregando uma hermenêutica bem distante da elitizada. Camargo e Cardoso (2015, p. 164) esclarecem que

[...] nessas produçôes geralmente o pesquisador ou o literato pertence ao grupo opressor e/ou ex-colonizador. Chamam a atençâo os estudos pós-coloniais que indicam que o oprimido (e/ou ex-colonizado) também possui a capacidade intelectual de falar a respeito da opressáo, que o "subalternizado" pode falar por si mesmo. Carolina Maria de Jesus se enquadra nesse perfil. Além falar por si mesma, do lugar da opressấo, ela produz literatura a partir desse mesmo lugar de enunciaçăo, razóes pelas quais, talvez, isso resultou na sua invisibilizaçăo no cânone literário.

Ao empregar a locuçâo adjetiva de fronteira, evocam-se debates de autores como Mignolo (2003) e outros (QUIJANO, 2010), por sustentarem a existência teórica de uma subalternidade oriunda das relaçôes de poder travadas entre colonizado e colonizador. Nota-se que o termo fronteira foi preestabelecido desde os primórdios nascedouros da centralidade europeizada, visto que o nós e o eles tornam-se determinantes na visăo hierárquica, epistêmica e eminentemente racionalizada daqueles que subjugam e dos subjugados. Os dizeres de Van Dijk (2008) săo basilares para o momento. Acostumados a mandar, a tônica repousa nos seguintes aspectos: "[..] enfatizam os aspectos positivos do Nós, do grupo de dentro; enfatizam os aspectos negativos do Eles, do grupo de fora; náo enfatizam os aspectos positivos do Eles; nâo enfatizam os aspectos negativos do Nós." ( VAN DIJK, 2008, p.18). 


\section{CONSIDERAÇÕES PROVISÓRIAS}

Infere-se das discussōes travadas ao longo desta produçăo textual que a construçăo sígnica de Maria Carolina de Jesus, tomando como referência a produçăo textual autobriográfica denominada Favela, em dialogicidade com os estudos da Semiótica peirceana, estreitados aos que discutem a decolonialidade, é alicerçada pela posiçấo que ocupa, enquanto interpretante cultural de si e do outro. De Jesus (2014, p. 53-54) apresenta uma enorme consciência política, ao fazer a leitura dos signos quotidianos: "[...] os filhos dos operarios nâo tem infancia. Nâo tem brinquedos. [...] săo obrigados a trabalhar nas fabricas. [...] perdem os sonhos. [...] Qual foi o decreto do presidente Dutra que favoreceu os pobres?". Acresce-se a estes dizeres o fato de possuir um senso de responsabilidade para com o outro, repartindo o pouco que tinha: "[...] arrangei uns caderno e comecei a lecionar. [...] era um prazer ser útil aos favelados" (p. 61).

Percebe-se, entăo, que De Jesus tem consciência de sua negritude e do quanto esta condiçăo afeta o outro, quando ela passa a ser narradora de si mesma, denunciando as condiçôes em que vive, tendo como arma o texto literário. Corrobora-se, portanto, a hipótese inicial de que sua condiçăo de negra foi construída, ao longo da narrativa, pelos resquícios de uma colonialidade preconceituosa, relegando-a a margem enquanto subalternizada.

Como mulher aguerrida, De Jesus năo espera que ninguém lhe conceda a fala aleatoriamente. Ao contrário, ela arranca essa fala social de suas entranhas negras. Nada lhe é gratuito! Até mesmo o papel em que escreve carrega a semântica da labuta. Todavia, depara-se com os moldes estruturantes de uma sociedade capitalista, movida por interesses ancorados nos contêineres europeizados. A literatura canônica encontra-se nesta ordem que a coloca como subalterna.

Destarte, parafraseando Camargo e Cardoso (2014), considerando um provérbio africano - "Também o leăo deverá ter quem conte a sua história. As histórias nâo podem glorificar apenas o caçador", é relevante dizer que os escritos de Carolina de Jesus se enquadram no perfil da conjuntura pós-colonial literária brasileira. Esta premissa é muito empregada pela linha dos estudos pós-coloniais, visto que fica subentendida a ideia de que, mais importante do que alguém contar a história do "vencido", seria que o "vencido" contasse a sua própria história. "Carolina Maria de Jesus encontra-se nesse lugar. A literata a partir do seu lugar de enunciaçấo, ou seja, em sua condiçăo de mulher, negra e pobre, passa a contar sua memória individual que é, também, ao mesmo tempo, nossa história coletiva (CAMARGO E CARDOSO, 2014, p. 161).

Entretanto, apesar do silenciamento canônico, sua voz marginalizada ecoa, agora, nas academias universitárias como voz de resistência ao poder-saber da colonizaçăo, demarcando um lugar de luta e testemunho de quem năo se deixou vencer pelas amarras da discriminaçăo racial ou tampouco institucionais. 


\section{REFERÊNCIAS}

ARAÚJO, Inês Lacerda. Do Signo ao Discurso: introduçāo à filosofía da linguagem. São Paulo: Parábola Editorial, 2004.

BAUMAN, Zygmunt. O mal-estar da Pós-Modernidade. Traduçăo de Mauro Gama e Cláudia Martinelli Gama. Rio de Janeiro: Jorge Zahar, 1998.

Zahar, 2005.

Identidade. Traduçấo de Carlos Alberto Medeiros. Rio de Janeiro: Jorge

BALLESTRIN, L. 2013). América Latina e o giro decolonial. In: Revista Brasileira de Ciência Política, n¹1. Brasília: 2013. Disponível em http://dx.doi.org/10.1590/ S0103-33522013000200004. Extraído em dezembro de 2019. p. 89-117.

CAMARGO, Rita de Cássia; CARDOSO, Lourenço. Carolina e o drama da populaçăo descartável. In: Língua e Literatura. Săo Paulo: USP, 2014. Disponível em: https:// doi.org/10.11606/issn.2594-5963.lilit.2012.97536. Extraído em dezembro de 2019. p. 161-175.

CÈSAIRE, Aimé. Discurso sobre o colonialismo. Blumenau- SC: Letras Contemporâneas, 2010.

DAVIS, A. In: Conferência: Atravessando o tempo e construindo o futuro da luta contra o racismo. Salvador: UFBA/TVE, 2017.

DE JESUS, Carolina Maria. Favela. In: Onde estaes Felicidade? Dinha e Rafaela Fernandes (Orgs.). Săo Paulo: Me Parió Revoluçōes, 2014.

DELLEUZE, Gilles. Proust e os signos. Traduçăo Antonio Carlos Piquet e Roberto Machado. Rio de Janeiro: Forense Universitária, 2003.

FANON, Frantz. Pele negra, máscaras brancas. Rio de Janeiro: Fator, 1983.

FERNANDES, J. D. C.. Introduçấo à Semiótica. In: Linguagens: usos e reflexôes. Ana Cristina de Sousa Aldrigue; Jan Edson Rodrigues Leite. (Orgs.). V. 8. Joăo Pessoa-PB: Editora da UFPB, 2011.

FERNANDES, Rafaela Andrea. Prefácio. In: Onde estaes Felicidade? Dinha e Rafaela Fernandes (Orgs.). Săo Paulo: Me Parió Revoluçôes, 2014.

FOUCAULT. M. A Ordem do Discurso. Săo Paulo: Loyola, 1996.

GROSFOGUEL, Ramon; BERNARDINO-COSTA, Joaze. Decolonialidade e perspectiva negra. In: Revista Sociedade e Estado - Volume 31 Número 1. Brasília-DF: Scielo, 2016. Disponível em http://dx.doi.org/10.1590/S0102-69922016000100002. Extraído em outubro de 2019. p. 15-24.

GROSFOGUEL, Ramon. Para descolonizar os estudos de economia política e os estudos pós-coloniais: transmodernidade, pensamento de fronteira e colonialidade global. In: Revista Crítica de Ciências Sociais. N. 80, Coimbra: 2008. p. 115-147. 
GUIMARÅES, Geny Ferreira. Até onde Carolina nos leva com seu pensamento? Ao poder. In: Onde estaes Felicidade? Dinha e Rafaela Fernandes (Orgs.). Sâo Paulo: Me Parió Revoluçōes, 2014.

HALL, Stuart. Quando foi o pós-colonial? Pensando no limite. In: Da diáspora: identidades e mediaçóes culturais, Belo Horizonte: Editora UFMG, 2003. p. 101-131.

INOCÊNCIO, Nelson. Corpo negro na cultura visual brasileira. In: Educaçâo, Africanidades, Brasil. Brasília: MEC - SECAD - UNB - CEAD. Faculdade de Educaçâo, 2006.

JÚNIOR, Josué Ferreira Oliveira. Literatura, Fronteiras e Margens: Poéticas Fronteiriças na Fronteira Brasil-Paraguai. Línguas e Letras. Cascavel-PR: UNIOESTE, 2018. Disponível em: http://dx.doi.org/10.5935/1981-4755.20180003. Extraído em dezembro de 2019. p. 23-39

MIGLIEVICH-RIBEIRO, A. (2014). Por uma razăo decolonial: Desafios ético-político-epistemológicos à cosmovisăo moderna. In: Dossiê: Diálogos do Sul. V. 14. N. 1. Porto Alegre-RS: Civitas, 2014. Disponível em: http://dx.doi.org/10.15448/19847289.2014.1.16181. Extraído em novembro de 2019. p. 66-80.

MIGNOLO, Walter D. Histórias locais / Projetos globais: colonialidade, saberes subalternos e pensamento liminar. Belo Horizonte: Ed. UFMG, 2003.

MUNANGA, Kabengele. Construçâo da identidade negra no contexto da globalizaçăo. In: Vozes (além) da África. Ignacio G. Dourado (coord.); Gilvan Ribeiro e Renato Bruno (Orgs.). Juiz de Fora: Ed. UFJF, 2006. . Negritude: Usos e sentidos. São Paulo: Ática, 1988.

NÖTH, W. Panorama da Semiótica: de Platāo a Peirce. Săo Paulo: Annablume, 1995.

OLIVEIRA, Mirian Ribeiro de. A DISCURSIVIDADE DO NORMAL: UMA IDENTIDADE CONSTRUÍDA. Raído. V. 5, N. 9. Dourados-MS: UFGD, 2011. Disponível em: http://ojs.ufgd.edu.br/index.php/Raido/article/download/777/805. Extraído em março de 2018. p. 103-114

PEIRCE, Charles Sanders. Semiótica. Traduçăo de José Teixeira Coelho Neto. Săo Paulo: Perspectiva, 2008.

QUIJANO, Aníbal. Colonialidade do poder e classificaçăo social. In: Epistemologias do sul. Boaventura de Souza Santos e Maria Paula Meneses (Orgs.). Săo Paulo: Cortez, 2010. Disponível em: http://cvc.instituto-camoes.pt/conhecer/biblioteca-digital-camoes/pensamento-e-ciencia/2106-2106/file.html. Extraído em outubro de 2019. p. 84-130.

QUINTERO, Pablo et al. Uma breve história dos estudos decoloniais. In: MASP Aftrall. Amanda Carneiro (Org.). Traduçâo de Sérgio Molina e Rubia Goldoni. Sáo Paulo: Museu de Arte de Săo Paulo Assis Chateaubriand, 2019. Disponível em: https:// masp.org.br/uploads/temp/temp-QE1LhobgtE4MbKZhc8Jv.pdf. Extraído em novembro de 2019. p. 1-12. 
SANTAELLA, L; NÖTH, Winfried. IMAGEM: cogniçāo, semiótica, mídia. Săo Paulo: Iluminuras, 2008.

SANTAELLA, Lúcia. O que é semiótica. Săo Paulo: Brasiliense, 2003.

Ed., 1992. . A Assinatura das Coisas - Peirce e a Literatura. Rio de Janeiro: Imago .Teoria geral dos signos. Săo Paulo: Pioneira, 2000.

SANTOS, Milton. O retorno do território. En: Debates: Territorio y movimientos sociales. Año 6. no. 16. Buenos Aires : OSAL : Observatorio Social de América Latina. CLACSO, 2005. Disponível em: http://bibliotecavirtual.clacso.org.ar/ar/libros/ osal/osal16/D16Santos.pdf. Extraído em setembro de 2018. p. 249-261.

SAUSSURE, Ferdinand de. Curso de Linguística Geral. Săo Paulo: Cultrix, 2004.

VAN DIJK, T.A. 2008. Racismo e Discurso na América Latina. Săo Paulo: Contexto, 2008. 